\title{
Evaluation of Calcium Aluminate/Calcium Phosphate Based Biocements as Root-end Filling Material
}

\author{
M.M.RADWAN ${ }^{1}$, H.K.ABD EL-HAMID ${ }^{1 *}$, H. H. ABO-ALMAGED ${ }^{1}$, \\ HAIDY N.SALEM ${ }^{2}$ and NADA OMAR ${ }^{2}$

\begin{abstract}
${ }^{1}$ Refractories, Ceramics and Building Materials Department, National Research Centre (NRC), Dokki, 12622 Cairo, Egypt.

${ }^{2}$ Restorative and Dental Materials Department, National Research Centre (NRC), Dokki, 12622 Cairo, Egypt. ${ }^{*}$ Corresponding author E-mail:hanaa772004@yahoo.com
\end{abstract}

http://dx.doi.org/10.13005/ojc/330602

(Received: September 28, 2017; Accepted: October 20, 2017)

\begin{abstract}
Nano-particles of pure single phase calcium aluminate $(C A)$ were prepared via solid state reaction at high temperature. An ultra-pure nano-size hydroxyapatite (HA) prepared by sol-gel method was used to formulate a composite of 1:1 CA: HA. Setting times, micro-hardness, bulk density, calcium ion and phosphorus ion concentration, XRD, FTIR and scanning electron microscopy (SEM) were investigated. The results showed that the substitution of $50 \%$ by weight of pure calcium aluminate cement $(\mathrm{CA})$ by nano-size hydroxyapatite $(\mathrm{HA})$ has a retardation effect on setting process. The use of artificial saliva solution as hydration medium enhances the hydration process of both synthesized calcium aluminate based materials due to the formation of more hydrated compounds. Curing of calcium aluminate cement in hot and humid conditions, resulting in hardness loss and high porosity due to the conversion process, in which the compounds $\mathrm{CAH}_{10}$ and $\mathrm{C}_{2} \mathrm{AH}_{8}$ (hexagonal crystals) are converted into the more stable compound $\mathrm{C}_{3} \mathrm{AH}_{6}$ (cubic crystals). The SEM studies indicated that the presence of nano-particles of hydroxyapatite in CA/ $\mathrm{HA}$ composite facilitated the precipitation of hydroxyapatite-like active layer, suggesting that pure CA cement has some distinctive physico-mechanical properties make it suitable for use as root end filling materials in dental applications.
\end{abstract}

Keywords: Nano-calcium aluminate - Nano-hydroxyapatite -Gibbsite -Root end material.

\section{INTRODUCTION}

Bioceramics that have been developed during the last five decades are especially used for repairing the skeleton bone systems as well as in dental applications ${ }^{1}$. These bioceramics comprising five main chemically bonded ceramics groups; Caphosphates, Ca-silicates, Ca-aluminates, Cacarbonates and $\mathrm{Ca}$-sulphates ${ }^{2,3}$. This investigation will be dealt with only two systems of the above mentioned five groups; those are calcium aluminate and calcium phosphate. 
The calcium aluminate phase used in this investigation was prepared in the laboratory from chemically pure starting materials by solid state reaction at elevated temperatures. The aluminate phase prepared by this method has a special benefit that is biocompatible. This type of calcium aluminate cement has a superior mechanical properties, especially after the first $24 \mathrm{~h}$ of hydration reaction that make it better material for load bearing applications as in dentistry. The curing of calcium aluminate cement occurs with high water consumption during setting and hardening of prepared pastes. The relatively high strength values of calcium aluminate pastes compared to those of calcium phosphate and also wide range variations in the consistency and formulations make it suitable for a wide range of applications ${ }^{3,4}$. There are five phases of calcium aluminate cements, that are $\mathrm{C}_{3} \mathrm{~A}$, $\mathrm{C}_{12} \mathrm{~A}_{7}, \mathrm{CA}, \mathrm{CA}_{2}$ and $\mathrm{CA}_{6}$, the most reactive one is the monocalcium aluminate $\mathrm{CA}\left(\mathrm{CaAl}_{2} \mathrm{O}_{4}\right)^{5}$.

Calcium phosphate cements are highly biocompatible as they are composed of cations and anions generally found in physiological media. These bioceramics have been widely used in both dental and orthopedic applications ${ }^{6,7}$. Hydroxyapatite $(\mathrm{HA})$ is an important phase among different forms of calcium phosphates as it is widely used as a bioactive ceramic powder in bone repairs and as coatings for metallic prostheses in order to improve the biological properties ${ }^{8,9}$. HA has a chemical structure very similar to that of human bone with a stoichiometric $\mathrm{Ca} / \mathrm{P}$ ratio of $1.67^{10}$. It could be also considered the main phase of bones and tooth structure ${ }^{11}$. Synthetic HA that has the same chemical composition of mineralized human bone and teeth shows great affinity to host hard tissues. The excellent stability of $\mathrm{HA}$ above $\mathrm{pH} 4.3$ and the chemical bond that is formed with the human tissue makes HA the ideal phase in clinical and dental applications in the human body ${ }^{8,12}$. Otherwise, mechanical reliability of pure HA ceramics is not sufficient, especially in wet environments as HA cannot be used as heavy loaded implants, such as artificial teeth or bone. Its medical applications are presently limited to smaller unloaded implants, powders, coatings and loaded porous implants ${ }^{13}$. Therefore, HA should be mixed with other load bearing material to formulate a composite characterized by good biological activity and better mechanical strength of cement ${ }^{14}$.
This investigation aims at studying the evaluation of pure CA base material as a root-end filling biocement. The influence of adding nanohydroxyapatite on sealing ability of the synthesized calcium-aluminate cement as root end filling material. Studying to some physicmechanical properties and hydration characteristics of two experimental calcium aluminate based formulations (CA and $\mathrm{CA} / \mathrm{HA}$ )cured in two different hydration media (distilled water and saliva solution) by studying setting times, micro-hardness test, calcium and phosphorus ion concentration in addition to X-ray diffraction analysis, infrared spectroscopy and scanning electron microscopy.

\section{MATERIALS AND METHODS}

Two different synthesized materials were prepared in laboratory by two different methods. The first denoted CA was composed of $80 \%$ of monocalcium aluminate $\mathrm{CA}$ and $20 \%$ of $\mathrm{BiO}_{2}$ (as filler to achieve radio opacity). The second, denoted $\mathrm{CA} / \mathrm{HA}$ was consisted of $40 \%$ of monocalcium aluminate CA, $40 \%$ of hydroxyapatite $\mathrm{HA}$ and $20 \%$ of $\mathrm{BiO}_{2}$.

\section{Materials preparation and characterization Preparation of monocalcium aluminate (CA)}

For the formation of CA phase, a dry-mixed 1:1 mixture of $\mathrm{CaCO}_{3}$ and $\mathrm{Al}_{2} \mathrm{O}_{3}$ (highly pure limestone $(\approx 99.8 \%)$ and Alumina $\left(99.6 \% \mathrm{Al}_{2} \mathrm{O}_{3}\right)$ were used. The two materials were mixed and pressed into cubes and fired at $1000^{\circ} \mathrm{C}$ for $2 \mathrm{~h}$, The product was ground, remolded with the aid of carbon tetrachloride and fired at $1500^{\circ} \mathrm{C}$ for $6 \mathrm{~h}$ agreed with all other studies, and mean that the levels of $\mathrm{C}_{12} \mathrm{~A}_{7}$ and $\mathrm{CA}_{2}$ decreased while the $\mathrm{CA}$ increased with increasing temperature and time ${ }^{15,16}$. The synthesized powder was investigated by Xray diffraction to verify the identity of the synthesized compound, using a copper target with radiation; wavelength $=0.154 \mathrm{~nm}$, X-ray was generated at 40 $\mathrm{kV}$ with a current of 2-5-mA (Fig.1). The synthesized material was grinded for $15 \mathrm{~h}$ in an agate mill until the desired grain size(15-32 nm). It was investigated by a Transmission Electron Microscope (JEM-1230) at $100 \mathrm{KV}$ to evaluate the particle diameter (Figure. 2.a).

\section{Preparation of Hydroxyapatite (HA)}

Calcium nitrate tetra hydrate, di-ammonium hydrogen phosphate and ammonium hydroxide 
were used for preparation of $\mathrm{HA}^{17}$. The stoichiometry of calcium nitrate and di-ammonium hydrogen phosphate solution was adjusted to get $(\mathrm{Ca} / \mathrm{P})$ molar ratio 1.68. HA was performed by slow addition of $(0.6 \mathrm{M})$ of di-ammonium hydrogen phosphate to (1 $\mathrm{M})$ of calcium nitrate under continuous stirring. The $\mathrm{pH}$ of the reaction mixture was adjusted at 11 by the addition of $\mathrm{NH}_{4} \mathrm{OH}$. The milky gelatinous precipitate was left to digest under reflux at $65^{\circ} \mathrm{C}$ for 1 hours. The prepared HA undergo thermal treatment at $1000^{\circ} \mathrm{C}$ for 2 hours. The formed phase was investigated by $\mathrm{X}$-ray diffraction analysis (Fig.3). The average size of $\mathrm{HA}$ particles lie in the nano range between 18 to $31 \mathrm{~nm}$ (Figure. 2.b).

Two types of aqueous solutions, namely, distilled water and saliva solution were used as curing liquids for the pastes. The chemical composition of the artificial saliva solution is given in Table $1 \cdot^{18}$. Distilled water was used as a mixing liquid to prepare pastes of calcium aluminate (CA) and calcium aluminate/hydroxyapatite composite $(\mathrm{CA} / \mathrm{HA})$. Trials were carried out with different amounts of distilled water to achieve the best workable consistency. The speculation of the powder incorporated into the liquid phase was done as successive fractions, one sixth of the powder was added every $15 \mathrm{~s}$ and kneaded with a spatula between addition to produce a paste with a workable consistency. The sample exhibited a string of one inch as the spatula was raised slowly from the glass slab.

\section{Setting time}

Five scoops ( $1 \mathrm{scoop}=0.2 \mathrm{gm}$ ) of the powder were mixed with five drops of each liquid to fill a mold of dimensions; $10 \mathrm{~mm} \pm 0.1$ - $\mathrm{mm}$ height. Mixing was done on a clean glass slab with a clean spatula, for 30 seconds. Each mold was placed on a glass plate $1 \mathrm{~mm}$ thick $\times 25 \mathrm{~mm}$ wide $\times 75 \mathrm{~mm}$ long and filled with the tested paste to a level surface. The stopwatch was started at the beginning of mixing. After $120 \pm 5 \mathrm{~s}$ from the beginning of mixing, the assembly was placed in a cabinet maintained at $37 \pm 1^{\circ} \mathrm{C}$ temperatures and $95 \%$ relative humidity. The Gilmore needle (having a flat end diameter of $2 \mathrm{~mm} \pm 01 \mathrm{~mm}$ ) was carefully lowered on to the horizontal surface of the material. Indentations were repeated at 30-second intervals until the indenture fails to make a complete circular indentation in the cement.

\section{Bulk density}

Bulk density was determined for the paste samples before the hardness test. Hardened cement samples were weighed suspended in water and in air as saturated surface dry. That was followed by drying the sample at $105^{\circ} \mathrm{C}$ for 24 hours. The dried samples were weighed in air after cooling in desiccators $^{19}$.

\section{Hardness test}

The prepared pastes of both synthesized materials were poured into a cylindrical brass mold (diameter $=10 \mathrm{~mm}$, height $=2 \mathrm{~mm}$ ). The paste was placed in the mold into two approximately equal layers. Each layer was compacted and pressed along the surface of the mold until homogenous specimen was obtained. Immediately after molding, the samples were cured in a humidity chamber at $100 \%$ relative humidity at a constant temperature of $37{ }^{\circ} \mathrm{C}$ for $24 \mathrm{~h}$. At the end of the moist curing period the samples were demoulded and then cured under the two types of aqueous solutions (distilled water and saliva) until the time of testing such as 1 , 3,7 and 14 days at a constant temperature of $37^{\circ} \mathrm{C}$. The hardness test ${ }^{20}$ was carried out on three cubes of each case of the hardened cement pastes. The test was performed with a Vickers indentation hardness tester at five points on one side of each sample. A load of $1 \mathrm{Kg}$ was applied for 15 seconds. The depth of indentation was then recorded.

\section{Calcium and phosphorus ion concentration}

The concentrations of calcium and phosphorus ion released of the teeth injected by the two experimental pastes were measured by atomic absorption spectra (Savant AA, GBC, Australia). A total of 20 prepared teeth were used to measure the concentrations of calcium and phosphorus ion released of the experimental teeth injected after one week and one month were measured by atomic absorption spectra.

\section{ATR/FTIR spectroscopy}

IR spectra were recorded on some selected samples with the aid of JASCO 4600 model FTIR spectrometer.

\section{Scanning electronmicroscopy (SEM)}

Scanning electron microscopy (SEM) model Philips XL30 was used to examine the marginal adaptation for group $A$ filled with $C A$ and 
in group $B$ filled with $\mathrm{CA} / \mathrm{HA}$ at root-end cavities after coating with gold thin films.Qualitative evaluation of the dentine cement interface was carried out. The penetration of the root-end filling materials in the dentinal wall irregularities, presence of gaps between the root-end materials and the dentinal walls, presence of voids or air bubbles, adaptation of the root-end materials and its proximity to the walls, the homogeneity of the root-end materials through its thickness and the presence of cracks in the root-end materials bulk were studied.

\section{Root-end filling procedures}

A total of 20 vital, freshly extracted and caries free human single-root teeth were collected from Cairo dental clinic at the National Research Centre. Teeth were stored in saline solution before the root-end filling procedures.

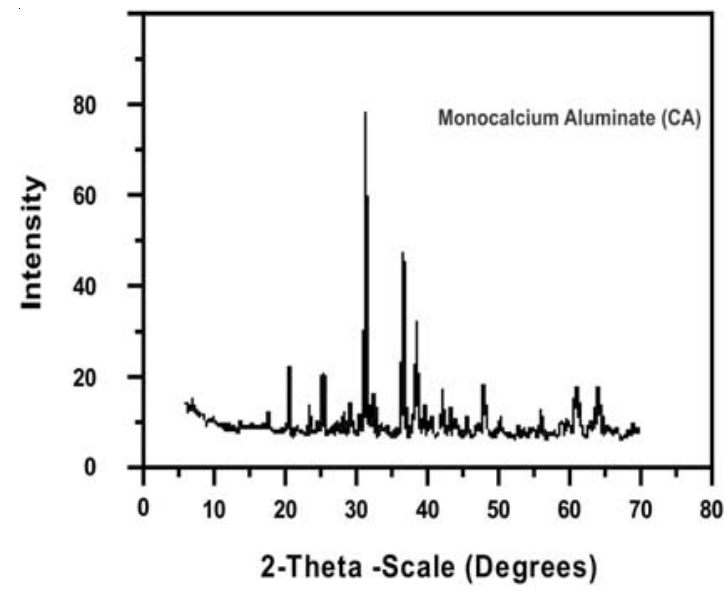

Fig. 1: XRD pattern of monocalcium aluminate (CA) powder fired at $1500^{\circ} \mathrm{C} / 6 \mathrm{~h}$

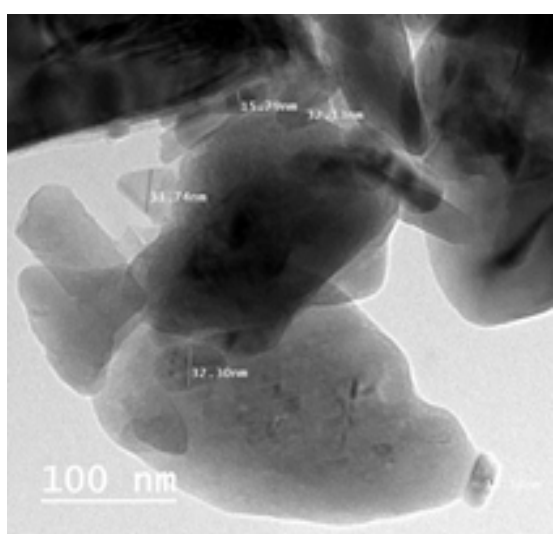

The teeth were decoronated by sectioning the coronal part of each tooth using a sectioning disc Toolouip, Germany, mounted on a low speed hand piece accompanied with water coolant. This was done for ease of manipulation and to standardize the tooth length at $15 \mathrm{~mm}^{21}$.

\section{Preparations of the teeth were carried out by the same operator as follow:}

Canal patency and working length were established using a size $15 \mathrm{~K}$ - file that was inserted into the root canal until the tip became visible at the apical foramen. Working length was then established at $1 \mathrm{~mm}$ short of the measured length. The root canals were instrumented with protaper nickel-titanium rotary system, in an electric endodontic motor (X-Smart) set at $300 \mathrm{rpm}$ and torque $1.2 \mathrm{Ncm}$. Each canal was enlarged to size \#F3. During instrumentation, $1 \mathrm{ml}$ of $5.25 \% \mathrm{NaOCl}$ was used to irrigate the canal between file sizes. Upon completion of instrumentation, $5 \mathrm{~mL}$ of $\mathrm{NaOCl}$, followed by $5 \mathrm{~mL}$ of $17 \%$ EDTA were used to remove the smear layer. Finally, fluid flush with distilled water was then carried out. Canals were dried with absorbent paper points prior to obturation.The root canals were filled with guttapercha (GP) points F3. AH plus sealer was mixed according to manufacturer's instructions. Master apical cone of size \#F3 was coated with the sealer and slowly inserted into the canal to the working length. A spreader \#30/0.02 taper was used for lateral compaction. Spreader was inserted in the canal alongside the master cone. Pressure was applied apically to push the spreader in as far as possible. Guttapercha cones (\#20/0.02 or \#25/0.02

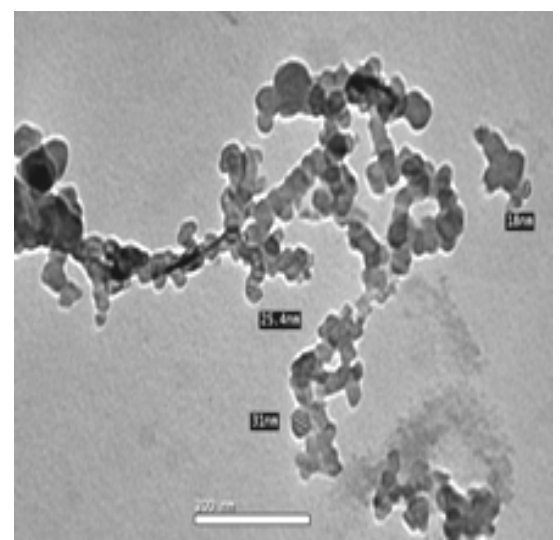

Fig. 2: Transmission electron photomicrograph of the two nano-sized synthesized materials: (a) monocalcium aluminate and (b) hydroxyapatite 
taper) were coated with the sealer and used as accessory cones, until there was no more room in the canal for additional accessory cones.

After sealing of all access cavities with Coltosol, an apical resection at $90^{\circ}$ to the long axis of the tooth was made at $3 \mathrm{~mm}$ from the end of the root. Root-end cavities of $3 \mathrm{~mm}$ were prepared with an ultrasonic tip (S12/90D-Gnatus, Brazil). Once prepared, teeth were randomly divided in two groups $A$ and $B$. Root-end fillings were performed in group $A$ with $C A$, and in group $B$ root-end cavities were filled with $\mathrm{CA} / \mathrm{HA}$. All samples were stored in humid environment at $37^{\circ} \mathrm{C}$ for one week to allow sufficient time for the root-end filling materials to set.The marginal adaptation was evaluated in groups $\mathrm{A}$ and $\mathrm{B}$.

\section{RESULTS}

\section{Setting time}

The setting time values of the pure CA phase and the prepared 1:1 CA/HA composite are presented in Fig. 4. The data shows a little delay in setting time of $\mathrm{CA}$ material upon substitution it by $50 \mathrm{wt} \% \mathrm{HA}$. This minute increase in setting time of $\mathrm{CA}$ in the presence of hydroxyapatite may be acceptable when using these materials in dental biomedical applications as calcium aluminate phase has a relatively fast curing process during the first $24 \mathrm{~h}$ that help minimizing the fluid leakage ${ }^{22}$.

\section{Bulk density}

The influence of using artificial saliva solution as a curing medium in comparison with

Table. 1: Composition of the artificial saliva solution

\begin{tabular}{|c|c|}
\hline Ingredients & $\begin{array}{c}\text { Concentration } \\
(\mathrm{g} / \mathrm{L})\end{array}$ \\
\hline $\mathrm{NaCL}$ & 0.4 \\
\hline $\mathrm{KCl}$ & 0.48 \\
\hline $\mathrm{CaCl}_{2} \cdot 2 \mathrm{H}_{2} \mathrm{O}$ & 0.795 \\
\hline $\mathrm{Na}_{2} \mathrm{~S} \cdot \mathrm{H}_{2} \mathrm{O}$ & 0.005 \\
\hline $\mathrm{NaH}_{2} \mathrm{PO}_{4} \cdot 2 \mathrm{H}_{2} \mathrm{O}$ & 0.78 \\
\hline Urea & 1 \\
\hline \multicolumn{2}{|c|}{ Phosphoric acid to adjust $\mathrm{pH}$ to 6.4} \\
\hline Distilled water & \\
\hline
\end{tabular}

distilled water on some physico-mechanical properties of the prepared pastes of both synthesized materials was studied. Fig. 5 indicates that the density values of pastes of pure CA increase from 1 to 3 days followed by a little decrease from 3 to 14 days, these values were found to be higher for samples cured under saliva solution. For pastes prepared form CA/HA composite, there is a continues increase in the density values from one up to 14 days curing period, but for pastes cured for 7 and 14 days in saliva medium, there was a slight increase in density values.

\section{Micro-hardness test}

The measured hardness values of both investigated materials cured under distilled water and saliva solution are graphically represented in Fig.6 (a\&b). The samples of pure CA showed (Fig.6.a) a steady decrease in hardness Vickers values with curing periods for both hydration media, while, those prepared from CA/HA composite (Fig.6.b) there is an increase in the hardness values up to 3 days followed by a decrease at 14 days curing age hydration media. Fig.6.b indicates that the hardness values of samples cured using saliva are higher than those cured under distilled water at all curing ages.

\section{Calcium and phosphorus ion concentration}

Fig. 7 illustrates the variations in calcium ion concentrations of samples cured for one week and one month. The data show a trace amount of $\mathrm{Ca}^{2+}$ ion in the hydration medium ranging from $\approx 0.5$ to $\approx 2 \mathrm{ppm}$. At one week curing age, samples of pure CA paste showed less $\mathrm{Ca}^{2+}$ ion than $\mathrm{CA} / \mathrm{HA}$

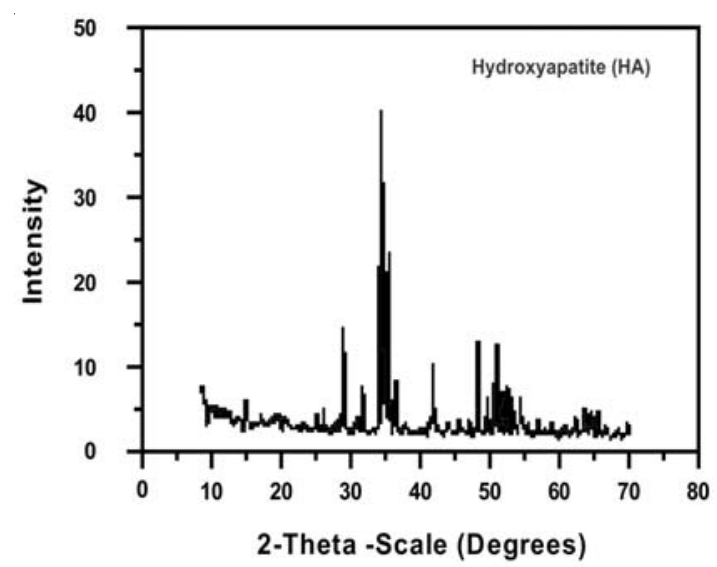

Fig. 3: XRD pattern of Hydroxyapatite powder fired at $1000{ }^{\circ} \mathrm{C} / 2 \mathrm{~h}$ 
composite, while at one month, the $\mathrm{Ca}^{2+}$ ion value of $\mathrm{CA} / \mathrm{HA}$ samples was less than those of $\mathrm{CA}$ sample. The values of phosphorus ion for pastes made of CA/HA composite and cured for one week and one month are represented in Fig. 8. The data revealed an increase in the $\mathrm{P}^{3-}$ ion concentration with the curing age from a week up to a month due to the dissolution of the apatite $(\mathrm{HA})$ in the hydration medium at $37^{\circ} \mathrm{C}$.

\section{X-Ray Diffraction}

The X-ray diffraction patterns of pastes of the two synthesized materials cured under distilled water and saliva solution for 1 and 14 days are represented in Fig.9(a\&b). The X-ray patterns of pure CA phase Fig.9.a showed a decrease in the peak height of the anhydrous monocalcium aluminate (CA) with curing period from 1 to 14 days in both distilled water and saliva solution. The characteristic peaks of the two main hydration

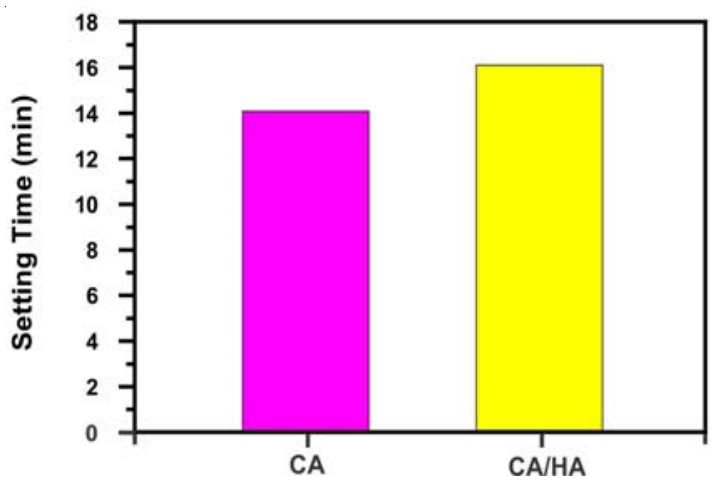

Fig. 4: The setting time values of the pure CA phase and the prepared CA/HA composite

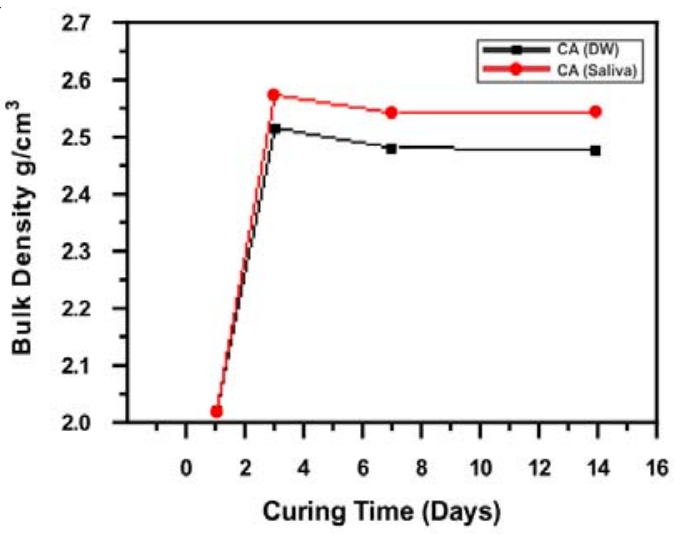

products $\left(\mathrm{CAH}_{10}\right.$ and $\left.\mathrm{C}_{2} \mathrm{AH}_{8}\right)$ could be detected either in a short height or overlapping on those of the anhydrous phase. X-ray peaks characteristics for Gibbsite $\left(\mathrm{AH}_{3}\right)$ and hydrogarnet $\left(\mathrm{C}_{3} \mathrm{AH}_{6}\right)$ are clearly found as a result of the conversion process of the principal hydration compounds, $\mathrm{CAH}_{10}$ and $\mathrm{C}_{2} \mathrm{AH}_{8}$, at $37^{\circ} \mathrm{C}$. The XRD data of the selected hydrated pastes reveals that the use of saliva solution enhances the hydration process. On the other hand, Fig.9.b that displays the diffraction patterns of the CA/HA composite showed an increase in all peak height of the anhydrous CA materials and enhancement of the hydroxyapatite (HA) characteristic peak height.

\section{IR spectroscopy}

FT-IR spectroscopy was employed to investigate the hydrated phases of some selected hydrated phases. Fig. 10 and Table. 2 illustrate the changes of the IR bands with hydration periods for pure CA phase cured in saliva solutions and distilled water. Fig. 10 shows the typical band of $\mathrm{CAH}_{10}$ at $3500 \mathrm{~cm}^{-1}$ due to the $\mathrm{OH}^{-}$valence vibration and the band in the range $1650-1600 \mathrm{~cm}^{-1}$ for the $\mathrm{H}-\mathrm{O}-\mathrm{H}$ bending vibration. These two bands show their maximum at 3 days for CA pastes cured in distilled water (Fig. 10(a)) that is due to the increase in the hydration products, then these two bands diminish at 7 days followed by an increase at 14 days curing period, while in case of pastes cured in saliva solution there is a steady decrease in that IR bands. The Al-O vibration bands at about 520-550 $\mathrm{cm}^{-1}$ and $800-850 \mathrm{~cm}^{-1}$ were detected for CA pastes cured in both distilled water and saliva (Fig. 10

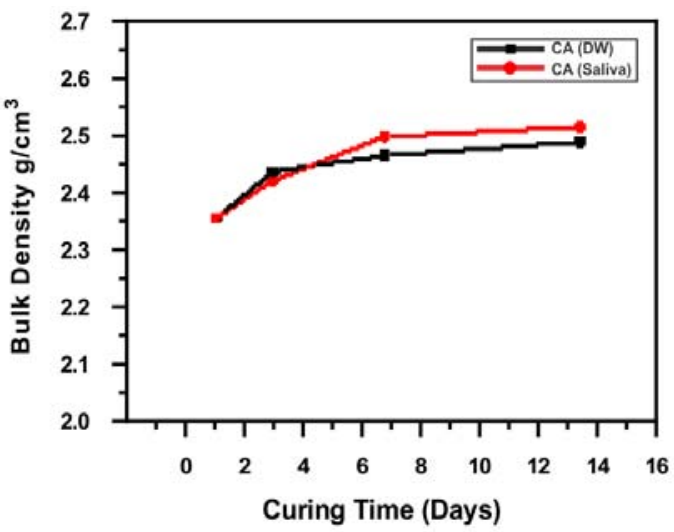

Fig. 5: Bulk density of; (a) pure CA and (b) CA/HA composite cured in distilled water and artificial saliva 
$(a, b))$, these IR bands are decreased with curing period. The IR spectrums given in Figs. 10\& $11(a, b)$ also show the band corresponding to the $\mathrm{v}_{3} \mathrm{CO}_{3}{ }^{2-}$ at $1500-1400 \mathrm{~cm}^{-1}$ and the duplets at $500-400 \mathrm{~cm}^{-1}$ due to the partial carbonation of the hydration products. The typical absorption bands of $\alpha-\mathrm{Al}(\mathrm{OH})_{3}$ could be detected at about $1100-1000 \mathrm{~cm}^{-1}$ and small one at $970 \mathrm{~cm}^{-1}$ as can be seen in Figs. 10\&11(a,b). The vibrations of the $\mathrm{C}_{3} \mathrm{AH}_{6}$ are detected in the range between $600-500 \mathrm{~cm}^{-1}$ and may overlap with that of the $\mathrm{Al}-\mathrm{O}_{6}$ in the range which will increase with the hydration reaction time. Fig. $11(a, b)$ illustrates the IR spectrums of pastes of composite bio-ceramic $\mathrm{CA} / \mathrm{HA}$ cured in distilled water and the artificial saliva solution for $1,3,7$ and 14 days. All the mentioned IR bands that are found in Fig. $10(a, b)$ could be

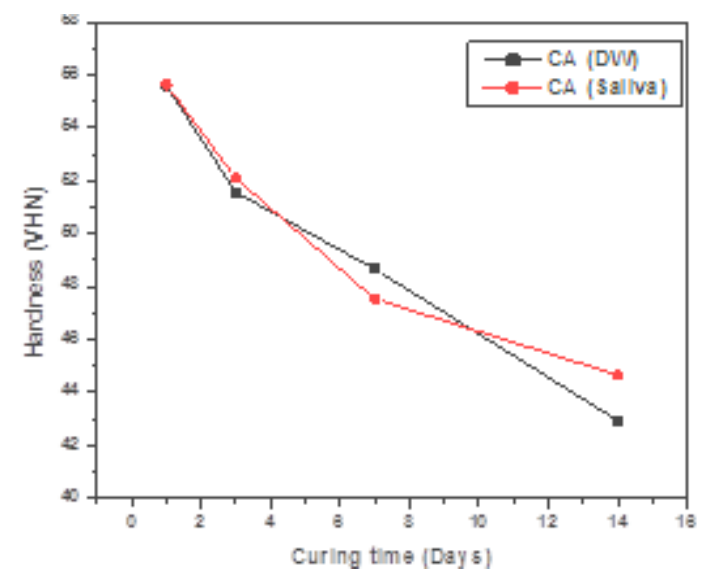

detected for pastes of $\mathrm{CA} / \mathrm{HA}$ composite in addition to those corresponding to typical IR bands of $\mathrm{PO}_{4}{ }^{3-}$ . The IR band corresponds to $\mathrm{CAH}_{10}$ at $3500 \mathrm{~cm}^{-1}$ due to the $\mathrm{OH}^{-}$valence vibration and that at 1650 $1600 \mathrm{~cm}^{-1}$ for the $\mathrm{H}-\mathrm{O}-\mathrm{H}$ bending vibration show a decrease from 1 to 3 days and then an increase again for 7 and 14 days curing age of the two hydration media (Fig. $11(a, b))$, but this behavior is not noticeable for paste cured in saliva solution. The typical IR band of the $\mathrm{v}_{3} \mathrm{CO}_{3}{ }^{2}$-at $1500-1400 \mathrm{~cm}$ 1'and the duplets at $500-400 \mathrm{~cm}^{-1}$ are also found in Fig. $11(a, b)$ due to the partial carbonation of the hydration products. The main IR bands corresponding to hydroxyapatite due to the symmetric stretching of $\mathrm{v}_{3} \mathrm{PO}_{4}{ }^{3}$-at $1100-1060 \mathrm{~cm}^{-1}$ and $\mathrm{v}_{4} \mathrm{PO}_{4}{ }^{3-}$ bending at 650 and $560 \mathrm{~cm}^{-1}$ could be

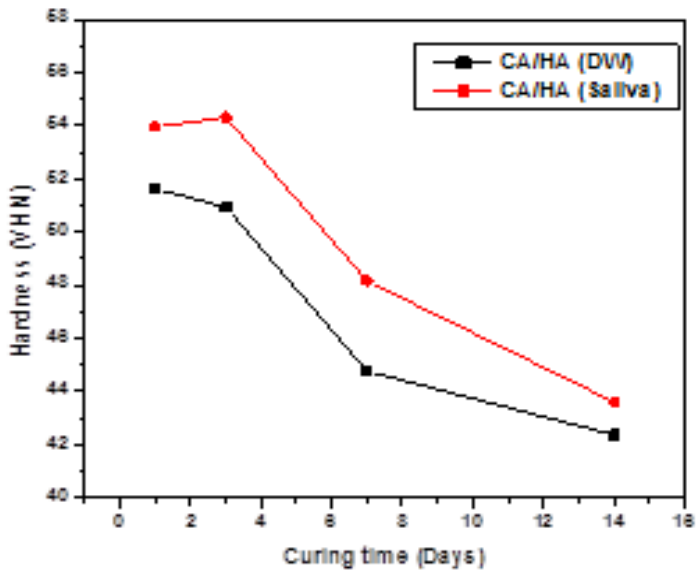

Fig. 6. Micro-hardness data of (a) pure CA and (b) CA/HA composite cured in distilled water and artificial saliva

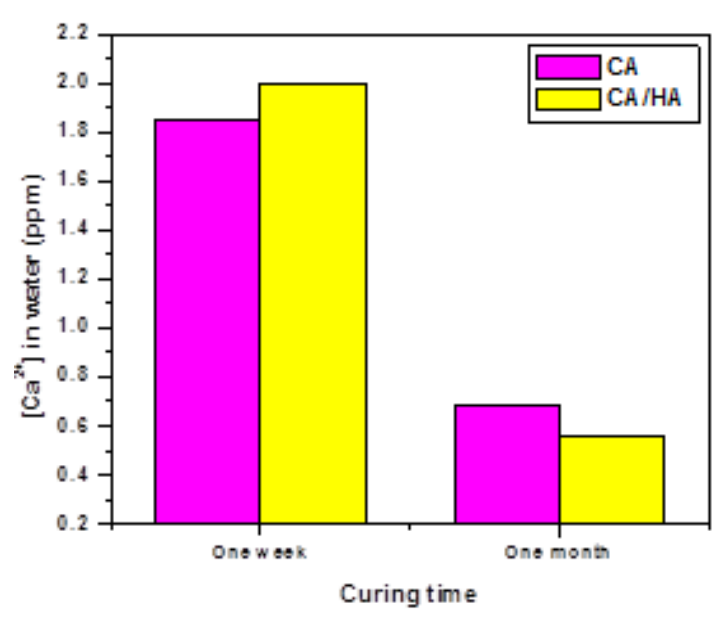

Fig. 7. Calcium ion concentration of pure CA and $\mathrm{CA} / \mathrm{HA}$ composite cured in distilled water

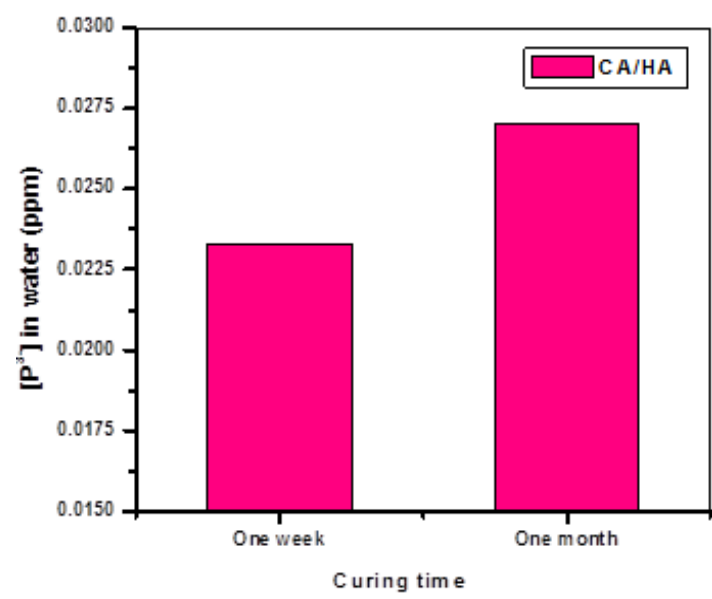

Fig. 8. Phosphorus ion concentration of CA/HA composite cured in distilled water 
detected in both graphs and overlapping with those of absorption bands of $\alpha-\mathrm{Al}(\mathrm{OH})_{3}$ at about $1100-1000 \mathrm{~cm}^{-1}$ and small one at $970 \mathrm{~cm}^{-1}$ and the vibrations of the $\mathrm{C}_{3} \mathrm{AH}_{6}$ in the range between $600-500 \mathrm{~cm}^{-1} .23$. All the aforementioned IR bands given in Figs. 10,11 show a decreasing trend with the curing age from 1 up to 14 days for the two hydration media except for pastes cured for 3 days in saliva solution, a deep diminishing of all IR bands of all hydrated phases followed by an increase for 7 and 14 days samples.

\section{Scanning electron microscopy}

The SEM micrograph given in Fig.12 (a,b) showed that group $A(C A)$ had no adhesion between the material and tooth interface, and gap formation at the interface after 1 week and 1 month. However, the interface between tooth and the CA/ $\mathrm{HA}$ based filling material after 1 week was homogeneous and did not show any gaps,,while at 1 month interval a tiny gap was observed between the material and tooth interface. Figure. 13(a,b).
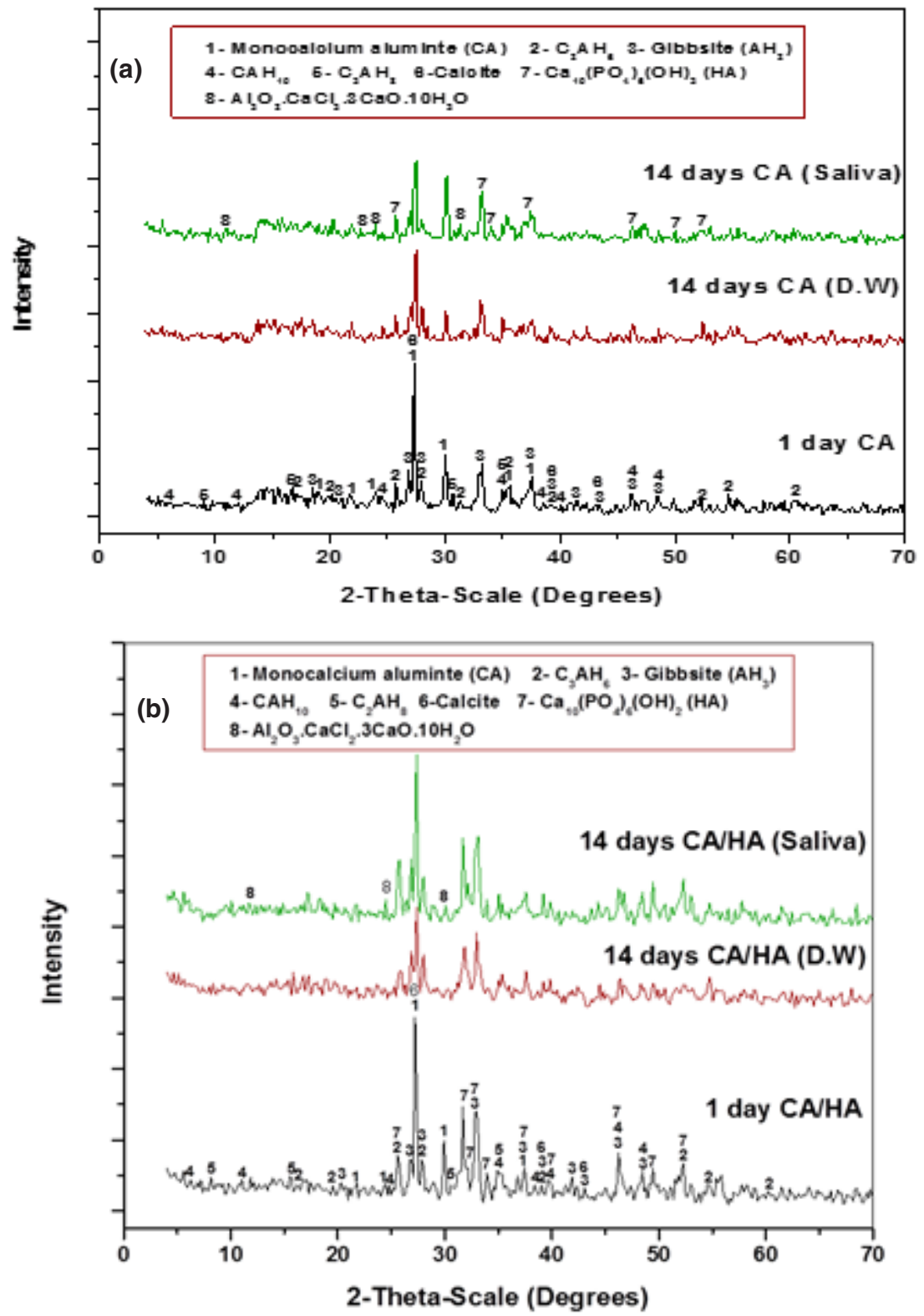

Fig. 9: XRD patterns for; (a) pure CA and (b) CA/HA composite cured for 1 and 14 days in distilled water and artificial saliva 


\section{DISCUSSION}

Calcium aluminate cement that is made from highly pure limestone or lime with bauxite or other aluminous material has special properties which include rapid strength development and good resistance to many forms of chemical attack. The essential aluminate phase that develops the main hydraulic activity and is consequently responsible for the strength development, is monocalcium aluminate, CA. Calcium aluminate cement hydrates with water and the major crystalline hydration products are $\mathrm{CAH}_{10}$ at low temperatures $\left(5-10^{\circ} \mathrm{C}\right)$, $\mathrm{C}_{2} \mathrm{AH}_{8}$ and $\mathrm{AH}_{3}$ at $22-35^{\circ} \mathrm{C}$ and $\mathrm{C}_{3} \mathrm{AH}_{6}$ (katoite) and $\mathrm{AH}_{3}$ (gibbsite) at $>35^{\circ} \mathrm{C}$. Depending upon temperature and curing period, all hydration products will be converted to $\mathrm{C}_{3} \mathrm{AH}_{6}$ and $\mathrm{AH}_{3}$ in process called conversion ${ }^{24,25}$. The strength loss of calcium aluminate cement cured in hot and humid conditions is mainly due to the so called, conversion process, in which the compounds $\mathrm{CAH}_{10}$ and $\mathrm{C}_{2} \mathrm{AH}_{8}$ (hexagonal crystals) are converted into the more stable compound $\mathrm{C}_{3} \mathrm{AH}_{6}$ (cubic crystals) in accordance to the following equations ${ }^{22}$ :

$3 \mathrm{CAH}_{10} \rightarrow \mathrm{C}_{3} \mathrm{AH}_{6}+2 \mathrm{AH}_{3}+18 \mathrm{H}^{*}$
$3 \mathrm{C}_{2} \mathrm{AH}_{8} \rightarrow 2 \mathrm{C}_{3} \mathrm{AH}_{6}+\mathrm{AH}_{3}+9 \mathrm{H}$

High early strength is one of the major advantages of calcium aluminate cement (CAC) over Portland cement. However, its high early strength is adversely affected by temperature as it

Table. 2: Results of FTIR analysis

\begin{tabular}{|c|c|}
\hline Wave number $\left(\mathrm{cm}^{-1}\right)$ & Crystal phase \\
\hline $400-5001400-1500$ & The $\mathrm{CO}_{3}{ }^{2}$-Stretching vibrations \\
\hline $600-500$ & The vibration of $\mathrm{C}_{3} \mathrm{AH}_{6}$ and may overlap with that of the $\mathrm{Al}-\mathrm{O}_{6}$ \\
\hline $550-520850-800$ & The Al-O vibrations \\
\hline $1100-1000$ & The absorption band of $\alpha-\mathrm{Al}(\mathrm{OH})_{3}$ \\
\hline $970-9901027$ & The O- $\mathrm{H}$ bending vibration attributed to gibbsite $\left(\mathrm{AH}_{3}\right)$ \\
\hline 3475,3530 and 3630 & The O- $\mathrm{H}$ stretching vibration attributed to gibbsite $\left(\mathrm{AH}_{3}\right)$ \\
\hline 524,3465 and 3670 & $\begin{array}{l}\text { The bands appearing of the water hydrated CAC paste }\left(\mathrm{CAH}_{10}, \mathrm{C}_{2} \mathrm{AH}_{8}\right. \\
\left.\text { and } \mathrm{C}_{3} \mathrm{AH}_{6}\right)\end{array}$ \\
\hline $1650-1600$ & The $\mathrm{H}-\mathrm{O}-\mathrm{H}$ bending vibration band of $\mathrm{CAH}_{10}$ \\
\hline $1100-1050$ & The symmetric stretching vibration of $\mathrm{v}_{3} \mathrm{PO}_{4}^{3-}$ \\
\hline $650-560$ & The $\mathrm{PO}_{4}^{3-}$ bending vibration \\
\hline
\end{tabular}

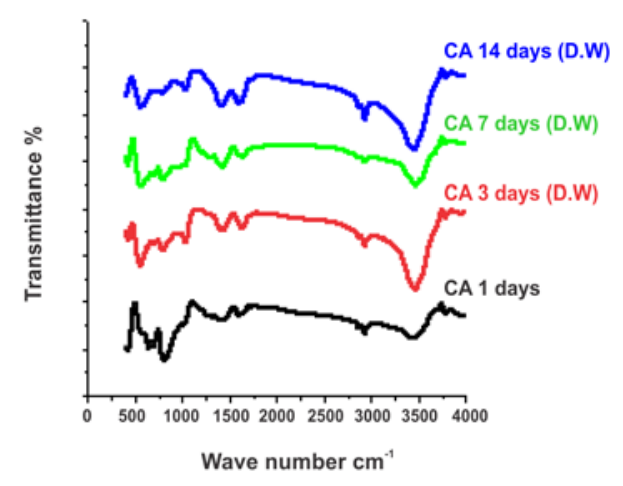

(a)

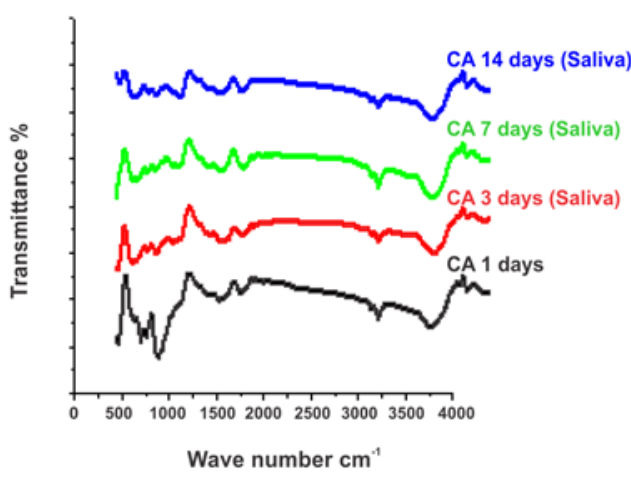

(b)

Fig. 10: IR spectra of pure CA cured for 1, 3, 7 and 14 days in: (a) distilled water and (b) artificial saliva 
enhances the conversion process. It was stated that the $\mathrm{CAH}_{10}$ and $\mathrm{C}_{2} \mathrm{AH}_{8}$ crystals are not stable in a humid and hot conditions, consequently, they will eventually convert to the more stable $\mathrm{C}_{3} \mathrm{AH}_{6}$. This will result in a strength reduction due to the formation of micro cracks in hardened structure ${ }^{26}$.

The setting time results, Fig. 4, showed a little retardation of setting time of CA material upon

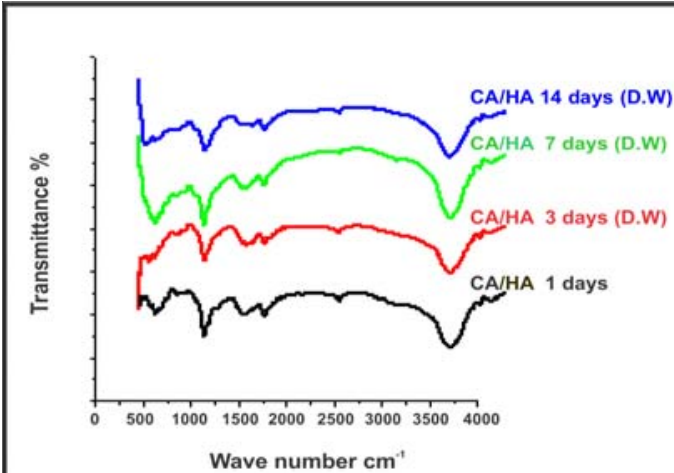

(a)

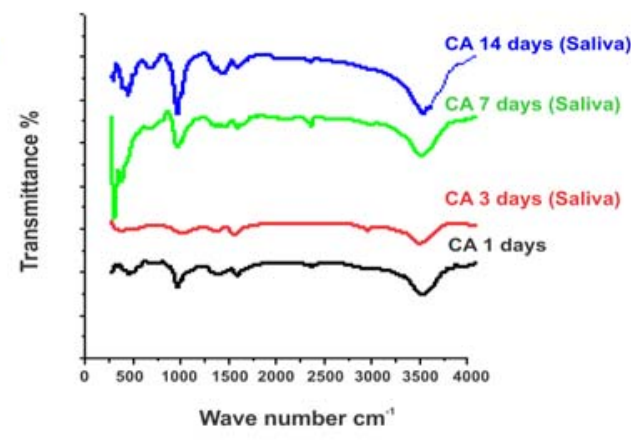

(b)

Fig. 11: IR spectra of CA/HA composite cured for 1, 3, 7 and 14 days in;

(a) distilled water and (b) artificial saliva

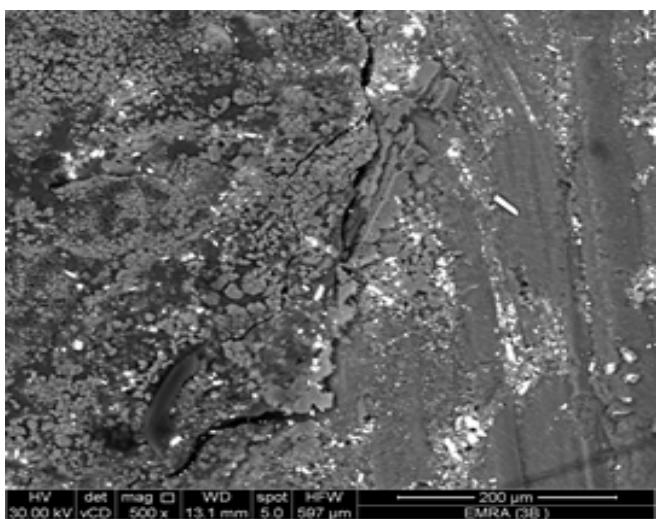

(a)

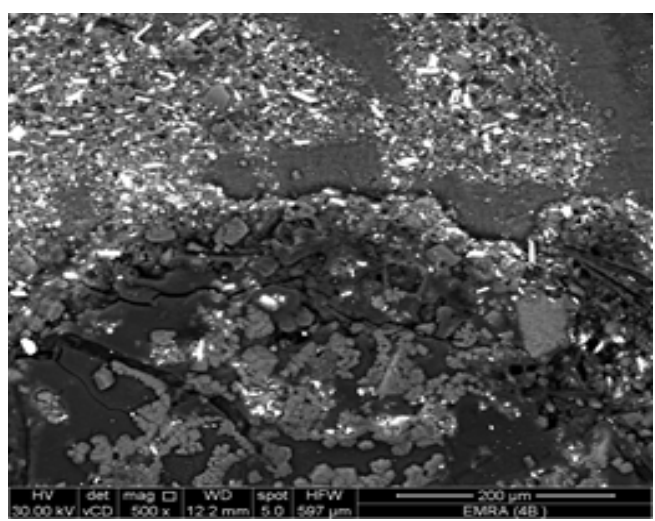

(b)

Fig. 12: SEM of pure CA group cured for one week (a) and one month intervals (b)

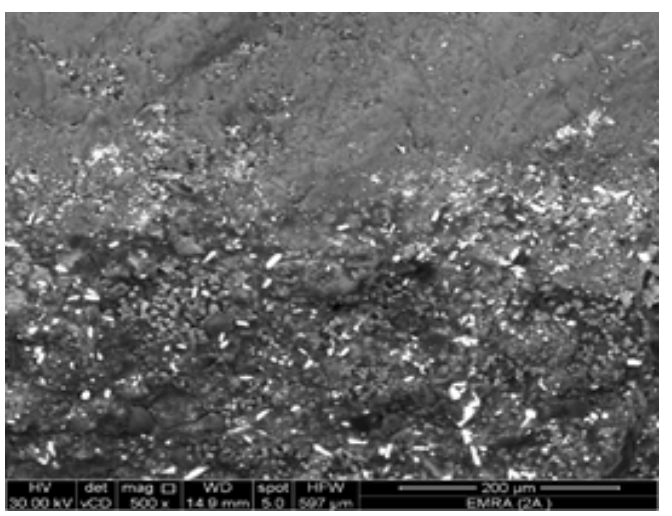

(a)

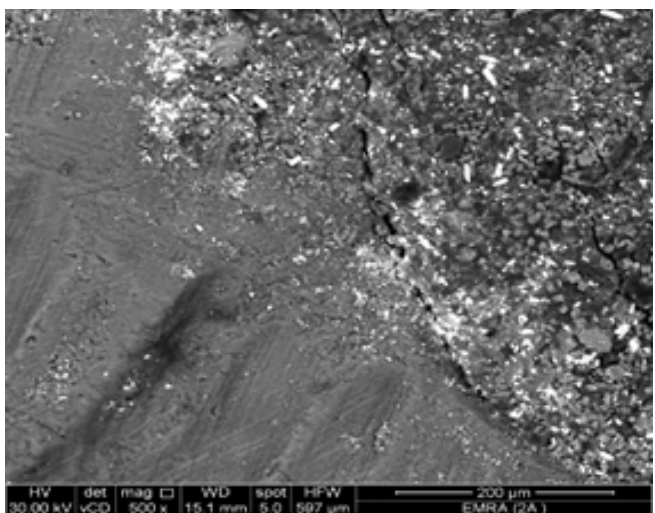

(b)

Fig. 13: SEM of CA/HA composite group cured for one week (a) and one month intervals (b) 
substitution it by $50 \mathrm{wt} \% \mathrm{HA}$. This retardation of setting time may be acceptable in dental biomedical applications as calcium aluminate phase has a relatively fast curing process during the first $24 \mathrm{~h}^{27-29}$. The setting process of CA cement starts immediately after mixing with water through, first, dissolution followed by precipitation of the major hydration phase $\mathrm{CAH}_{10}, \mathrm{C}_{2} \mathrm{AH}_{8}$ and $\mathrm{AH}_{3}$, the replacement of $50 \%$ of the base calcium aluminate cement by hydroxyapatite as a hydrated calcium phosphate will perhaps adversely affect the physical and mechanical properties of this type of cementing materials as a softening and dissolution of $\mathrm{HA}$ also will start upon mixing with water ${ }^{14}$. Curing of pastes prepared from the two composites was carried out at $37^{\circ} \mathrm{C}$ in distilled water and artificial saliva solution in order to investigate the hydration behavior as influenced by hydration medium. Since this material sets and harden in vivo there is always a certain amount of ion leakage. Earlier studies reported that the leakage and hardness of root end filling materials were all affected over time ${ }^{20}$. The conversion process that is occurred during hydration of CA phase has an adverse effect on physicomechanical properties of hardened CA pastes, namely, bulk density and micro-hardness measurements (Figs. 5,6). In this process the transformation of meta-stable hydrated compounds, $\mathrm{CAH}_{10}, \mathrm{C}_{2} \mathrm{AH}_{8}$ and $\mathrm{AH}_{3}$ to the stable $\mathrm{C}_{3} \mathrm{AH}_{6}$ and $\gamma-\mathrm{AH}_{3}$ is highly dependent on temperature of the curing medium ${ }^{25}$. The process of conversion is considered very critical for long curing periods due to the chemical and morphological changes during hydration of $\mathrm{CA}$. The conversion of hexagonal crystals $\left(\mathrm{C}_{2} \mathrm{AH}_{8}\right)$ to cubic crystals $\left(\mathrm{C}_{3} \mathrm{AH}_{6}\right)$ increases the porosity of the hardened paste while density and hardness will be adversely affected. The present of huge amount of $\mathrm{AH}_{3}$ gel makes the measurements of porosity very difficult as it precipitates inside the pores and encapsulates both of anhydrous and hydrated compounds. The increase of density values from 1 to 3 curing ages of pastes of both pure CA phase and composite material CA/HA (Fig. 5 , a\&b) is mainly due to the formation of hydrated compounds during the early hydration period at $37^{\circ} \mathrm{C}$ in addition to the filling effect of the added bismuth oxide as radio-opaque filler. For pure CA materials, the density values showed a little decrease at curing ages from 3 up to 14 days in both curing media as a result of conversion process. The presence of $50 \mathrm{wt} \%$ nano-size HA in composite material $(\mathrm{CA} / \mathrm{HA})$ will act as a filler material beside its role in improving the biocompatibility of calcium aluminate cement. This nano particles of HA will be rearranged in the pore system of the hardened paste, that enhances the density values especially at later ages of hydration ${ }^{14}$. The continuous decrease of the micro-hardness data (Fig. 6a,b) for both investigated systems is mainly due to the process of conversion that is responsible for the highlyporous system of both synthesized materials, in addition to the poor mechanical properties of the added hydroxyapatite in $\mathrm{CA} / \mathrm{HA}$ composite ${ }^{30}$. Investigation of density and hardness data of both indicates that the use of saliva solution as a curing medium enhances the hydration reactions of the investigated materials due to the presence of free cations and anions $\left(\mathrm{Na}^{+}, \mathrm{K}^{+}, \mathrm{Ca}^{++}, \mathrm{Cl}\right)$ present in saliva solution. These free radicals may accelerate the rate of hydration reaction of the CA cement ${ }^{31}$.

Since these materials set and harden in vivo, there is always a certain amounts of ion leakage into surrounding tissues depending upon phase composition and setting time. Generally, CA phase has a low leakage since the material has a short setting time and good cohesiveness. The gel phase $\left(\mathrm{AH}_{3}\right)$ together with the main hydrated compounds $\mathrm{CAH}_{10}$ and $\mathrm{C}_{2} \mathrm{AH}_{8}$ are formed immediately at the beginning of the hydration reaction. The hydration process starts via dissolution of CA phase in the aqueous curing medium producing $\mathrm{Ca}^{2+}, \mathrm{Al}(\mathrm{OH})_{4}$ and $\mathrm{OH}^{-}$ions followed by precipitation of the hydrated phases.

Hydration of CA cement can be expressed by the following chemical reactions ${ }^{32}$ :

$$
\begin{aligned}
& \mathrm{CA}+10 \mathrm{H} \rightarrow \mathrm{CAH}_{10} \\
& 2 \mathrm{CA}+11 \mathrm{H} \rightarrow \mathrm{C}_{2} \mathrm{AH}_{8}+\mathrm{AH}_{3} \\
& 3 \mathrm{CA}+12 \mathrm{H} \rightarrow \mathrm{C}_{3} \mathrm{AH}_{6}+2 \mathrm{AH}_{3} \\
& 2 \mathrm{CAH}_{10} \rightarrow \mathrm{C}_{2} \mathrm{AH}_{8}+\mathrm{AH}_{3}+9 \mathrm{H} \\
& 3 \mathrm{C}_{2} \mathrm{AH}_{8} \rightarrow 2 \mathrm{C}_{3} \mathrm{AH}_{6}+\mathrm{AH}_{3}+9 \mathrm{H}
\end{aligned}
$$

$\mathrm{C}_{3} \mathrm{AH}_{6}$ phase cannot form directly from solution but must be preceded by another phase with a process called conversion (eqs. 4,5) and becomes dominant over $\mathrm{C}_{2} \mathrm{AH}_{8}$ depending on the hydration temperature. 
The data of calcium ion concentrations (Fig. 7) of pastes cured under distilled water are higher after one week curing period than those cured for one monthfor both investigated materials because during hydration process most of calcium aluminate (CA) reacts to form the less soluble hydrated compounds mentioned above. Although, the hydroxyapatite (HA) phase in the composite $\mathrm{CA} / \mathrm{HA}$ is considered the hydrated form of calcium phosphate cement and it is slightly soluble in water, it showed a decrease in calcium ion concentration more than pure CA at later curing age that is attributed to the encapsulation of HA particles by the hydrated products in such a porous structure. Although the mechanical performance of synthetic $\mathrm{HA}$ is very poor it was used in this study in nanosize to improve the biocompatibility of CA cement ${ }^{30}$ The very minute phosphorous ion concentration (Fig. 8) of the composite CA/HA confirms the above mentioned encapsulation effect of the hydrated phases of CA around HA particles that may retard its dissolution in the immersing liquid.

Calcium aluminate cement is highly resistance to many aggressive media including, dilute acid solutions and natural waters that contain $\mathrm{CO}_{2}$ as a significant solute. This high resistance to chemical attack is mainly due to restricted penetration by aggressive medium. Pastes that had been exposed to hydration medium containing $\mathrm{Cl}$ and $\mathrm{SO}_{4}^{2-}$ showed a significant ingress of $\mathrm{Cl}^{-}$but very limited of $\mathrm{SO}_{4}^{2-33}$. Small amount of calcium chloroaluminate $\left(\mathrm{Al}_{2} \mathrm{O}_{3} \cdot \mathrm{CaCl}_{2} \cdot 3 \mathrm{CaO} \cdot 10 \mathrm{H}_{2} \mathrm{O}\right)$ may be formed due to the presence of calcium chloride $\left(\mathrm{CaCl}_{2}\right)$ in saliva solution that is used in this investigation as curing medium, while most of chloride ions $\left(\mathrm{Cl}^{-}\right)$seemed to be adsorbed on the $\mathrm{CAH}_{10}$. In a porous CA paste where conversion has occurred, a part of $\mathrm{C}_{3} \mathrm{AH}_{6}$ reacts with atmospheric $\mathrm{CO}_{2}$ in a process called carbonation to give calcite and hydrous alumina (alumina gel) that are precipitated in the pores and prevent water molecules needed to promote the reaction. This behavior is a strong evidence that calcium aluminate pastes has high resistance to various forms of attack due to some effects that impede the continuous penetration of aggressive cations and anions in addition to blocking of pores by the hydrated compounds ${ }^{33}$. The characteristic X-ray diffraction peaks of calcium aluminate chloride hydrate $\left(\mathrm{Al}_{2} \mathrm{O}_{3} \cdot \mathrm{CaCl}_{2} \cdot 3 \mathrm{CaO} \cdot 10 \mathrm{H}_{2} \mathrm{O}\right)$ and calcite could be detected in Fig. (9. a) that represents the XRD patterns of CA pastes cured in saliva for 14 days showed the characteristic XRD peaks of hydroxyapatite compound that may be precipitated in pores from saliva solution. The XRD patterns of composite CA/HA pastes, Fig. (9.b), also shows the main XRD peaks of calcium aluminate chloride hydrate and calcite for samples cured for 14 days in saliva solution. The XRD patterns in Fig. (9.a) indicate that curing of CA pastes in saliva solution enhances the hydration reaction that is clear from the diminishing trend of peak height of the anhydrous CA particles and the appearance of new peaks characteristic for the hydrated phases, while in case of CA/HA pastes, Fig. (9.b), an overlapping of main XRD peaks of HA with those of hydrated calcium aluminate is predominant. The bands corresponding to the $\mathrm{v}_{3}-\mathrm{CO}_{3}$ at $1500-1400 \mathrm{~cm}^{-1}$ and the duplets at $500-400 \mathrm{~cm}^{-1}$ that are given in IR spectrums (Fig. 10\&11 (a,b)), indicate the partial carbonation of the hydration products of the two synthesized materials. Fig. 10 (a) shows the maximum typical band of $\mathrm{CAH}_{10}$ at $3500 \mathrm{~cm}^{-1}$ due to the $\mathrm{OH}^{-}$valence vibration and the band in the range $1650-1600 \mathrm{~cm}^{-1}$ for the $\mathrm{H}-\mathrm{O}-\mathrm{H}$ bending vibration at 3 days for CA pastes cured in distilled water that is due to the encapsulation of the increasing amount of the hydration products resulting in little delaying in water penetration to anhydrous powder that is clear in bands diminish at 7 days followed by an increase at 14 days curing period. In case of pastes cured in saliva solution there is a steady decrease in that IR bands that is mainly attributed to highly ionized medium of saliva solution.

The SEM studies showed that the CA/HA specimens had formed a homogenous, tiny gap after 1 month. interface, Fig. 13(a\&b).Nevertheless, adhesive separation and gap formation at the interface were commonly found in CA groups in both tested periods. In addition a mesh-like apatite layer was observed in CA/HA Fig. 13, however, this layer was not observed in CA Fig. 12, indicating that the increasing of $\mathrm{HA}$ content to $50 \mathrm{wt} \%$ facilitated the precipitation of a hydroxyapatite-like active layer, suggesting that the HA feature favorable in vitro bioactivity ${ }^{20,27-29}$. On the other hand,CA group specimens adhesive separation had shown between the CA cement and the tooth surface among all samples.It is obvious that the $\mathrm{CA} / \mathrm{HA}$ 
contains a rather large proportion of entrained air. The source of the air is mainly the mixing method used on the material. Porosity is an intrinsic characteristic of calcium aluminate based cements and occurs as a result of the spaces between the anhydrous cement grains. These spaces are filled with water once the material hydrates. As the hydration reaction progresses, the hydration products fill these gaps and the porosity decreases. However the conversion process in which the metastable hydrated compounds, $\mathrm{CAH}_{10}, \mathrm{C}_{2} \mathrm{AH}_{8}$ and $\mathrm{AH}_{3}$ is transformed to the stable $\mathrm{C}_{3} \mathrm{AH}_{6}$ and $\gamma-\mathrm{AH}_{3}$ at the relatively high temperature of curing medium $\left(37^{\circ} \mathrm{C}\right)$ especially at later curing ages will increase porosity and results in a highly porous system ${ }^{34-36}$, Although pores have a significant effect on the mechanical properties of the cement but it also affects its physical properties and, subsequently, its behavior within its environment. Porosity has been shown to act as reservoir for precipitated HA phase during the hydration reaction which have an impact upon bio-remineralization ${ }^{36,38}$. The results indicated that the CA/HA facilitated the precipitation of a hydroxyapatite-like active layer, suggesting that filling the hair cracks due to the increasing porosity at later ages, that is favorable in vitro bioactivity. CA/ HA materials exhibit dissolution and precipitation behaviors during the hydration reaction. Hydroxyapatite plays a crucial role in tissue regeneration and maintaining function because of its bioactive surface.

\section{CONCLUSION}

The calcium aluminate cement is considered suitable for use as dental material as it has some distinctive hydration, physical and mechanical characteristics. The CA material sets and hardens in the humid environment without additional curing aids. The mechanism of setting and hardening is a dissolution followed by formation of the hydration phases that results in tight seal between the hardened cement and the tooth. Curing in hot and humid conditions results in more porous system due to the conversion process in which the compounds $\mathrm{CAH}_{10}$ and $\mathrm{C}_{2} \mathrm{AH}_{8}$ (hexagonal crystals) are converted into the more stable compound $\mathrm{C}_{3} \mathrm{AH}_{6}$ (cubic crystals). The little retardation of setting time upon substitution of $50 \%$ of $\mathrm{CA}$ by hydroxyapatite $(\mathrm{HA})$ may be acceptable in dental biomedical applications due to the relatively fast curing process during the first 24 hours. The presence of $50 \mathrm{wt} \%$ nano-size $\mathrm{HA}$ in the composite material (CA/HA) has superior filling effect beside its role in improving the biocompatibility of $\mathrm{CA}$ cement. The XRD and IR data reveal that the curing of both synthesized materials in saliva solution enhances the hydration reaction rate. The SEM studies showed homogenous, almost gap free, interface for CA/HA composite, while, adhesive separation and gap formation at the interface were commonly found in CA samples. The nano-particles of hydroxyapatite in the composite material will be rearrangement in the highly porous system and this may facilitate the precipitation of additional HA compound in the pores. The results showed that $\mathrm{CA} / \mathrm{HA}$ materials exhibit dissolution and precipitation behaviors during the hydration reaction. Hydroxyapatite plays an important role in tissue regeneration and maintaining function because of its bioactive surface.

\section{REFERENCES}

1. Hench, L.L.;Wilson,J.; An introduction to bioceramic Advanced series in ceramics, Singapore: World Scientific Publishing Co, Pte.Ltd.1993, 1.

2. Ducheyne,P.; Lemons,J. E.; Bioceramics: material characteristics versus in vivo behavior. New York: Ann NY Academy of Science.1998.

3. Roy, D.M.; New strong cement materials: Chemically bonded ceramics, Science.1987, 235(4789), 651-658.
4. Scrivener,K.L.;Capmas,A.;Calcium aluminate cements. In Hewlett PC, editor. Lea's Chemistry of Cement and Concrete. Arnold: Paris.1998, 1-12.

5. Chatterjee,A.K.; Zhmoidin,G.I.; Phase equilibrium diagram of the system calcium oxide-aluminum oxide-calcium fluoride, J. Mater. Sci.1972, 7, 93-97.

6. Cherng,A.M.; Chow,L.C.; Takagi,S.;In vitro evaluation of a calcium phosphate cement root canal filler/sealer, J. Endodontics. 
2001,27,613-5.

7. Hench, L.L.;Bioceramics, J. Am. Ceram. Soc. 1998, 81(7),1705.

8. Billottee,W.G.; Park,J.B.; Bronzino,J.D.; Ceramic Materials in Biomaterials: Principles and Applications, CRC Press, Boca Raton, FL. 2002.

9. Liu,D.M.;Troczynski,T.; Seng,W.J.T., Biomaterial. 2001, 22, 1721.

10. Bow,J.S.;Liou,S.C.; Chen,S.Y.; Biomaterials. 2004, 25, 3155

11. Seal,B.L.; Otero,T.C.; Panitch,A.; 'Polymeric biomaterials for tissue engineering and organ regeneration. Mater SciEng R. 2001 34,147-230.

12. Bauer,T.W.; Geesink,R.G.T.; Zimmerman , R.;Mcmohan,J.T.; Hydroxyapatite-coated femoral stems. Histological analysis of components retrieved at autopsy, J. Bone Joint Surg. Am. 1991, 73, 1439-1452.

13. Kamiya,K.; Yoko,T.; Tanaka, K.; Fujiyama,Y.; Growth of Hydroxyapatite in gel system, J. mater. Sci.1989, 24,827-832.

14. Oliveira,I.R.; Andrade, T.L.; Araujoa, K.C.M.L.;Luzb,A.P.;Pandolfelli, V.C.; Hydroxyapatite synthesis and the benefits of its blend with calcium aluminate cement, Ceramics International. 2016,42, 2542-2549.

15. Rivas Mercury, J.M.; De Aza,A.H.; Pena,P.; Synthesis of $\mathrm{CaAl}_{2} \mathrm{O}_{4}$ from powders: Particle size effect, Journal of the European Ceramic Society. 2005, 25, 3269-3279.

16. Iftekhar, S.; Grins, J.; Svensson, G.; Lööf, J.; Jarmar, T.; Botton,G.A.; Andrei, C.M.; Engqvist,H.; Phase formation of $\mathrm{CaAl}_{2} \mathrm{O}_{4}$ from $\mathrm{CaCO}_{3}-\mathrm{Al}_{2} \mathrm{O}_{3}$ powder mixtures. Journal of the European Ceramics Society. 2008, 14, 747-756.

17. Ibrahim, D.M.; Hegazy,W. H.; Mahgoub, A.E.; and Abo-almajed, H.; Preparation and characterization of calcium Hydroxyapatite, Commum. Fac. Sci. Univ. Ank. Series B.2000,46,33-46

18. Shetty,K. V.; Jhajharia, K.;Chaurasia,V. R.; Jhamb, A.; Rohra,V.; Sharma,A. M.; An in vitro evaluation of the effect of dentin deproteinization on coronal microleakage in endodontically treated teeth, J. Int. Soc. Prev. Community Dent. 2014, 4, 187-92. doi: 10. 4103/2231-0762.149036.

19. ASTM Designation: C373-88, Water absorption, bulk density, apparent porosity and apparent specific gravity of fired white ware products.1999.

20. Endod, J.; Characterization of the Mineral Trioxide Aggregate-Resin Modified Glass Ionomer Cement Interface in Different Setting Conditions. J. Endo. 2012, 38 (8),11261129. doi:10.1016/j.joen.2012.04.013.

21. Baranwal, A. K.; Paul,M. L.; Mazumdar, D.;Adhikari,H. D.;Vyavahare, N. K.;Jhajharia, K.; An ex-vivo comparative study of root-end marginal adaptation using grey mineral trioxide aggregate, white mineral trioxide aggregate, and Portland cement under scanning electron microscopy, J.Conserv. Dent. 2015,18(5),399-404. doi: 10.4103/ 0972-0707.164054

22. Taylor,H .F.W.; Cement chemistry, Academic Press Ltd., London, 1997.

23. Gadsden, J. A.; Infrared spectroscopy of mineral and related inorganic compounds, Butterworths. 1975, 16-26.

24. Luz, A.P.;Pandolfelli,V.C.; $\mathrm{CaCO}_{3}$ addition effect on the hydration and mechanical strength evolution of calcium aluminate cement for endodontic applications, Ceram. In. 2012, 38, 1417-1425.

25. Bushnell-Watson,S.M.; Sharp,J.H.; The effect of temperature upon the setting behavior of refractory calcium aluminate cements, Cem. Concr. Res. 1986, 16,875-884.

26. Jefferis,S.A.; Mangabhai,R.J.; Effect of temperature rise on properties of high alumina cement grout, Calcium Alumina Cement, Chapman and Hall, London. 1990, 363-371.

27. Nurit,J.;Margerit,J.; Terol,A.; Boudeville,P., $\mathrm{PH}-$ metric study of the setting reaction of mono phosphate monohydrate/calcium oxide-based cement, J. Mater Sci. Mater Med.1993,13,1007-1014.

28. Jefferies,S.;Lööf,J.;Pameijer,C. H.; Boston,D.; Galbraith,C.;Hermansson,L.; Physical properties and comparative strength of a bioactive luting cement, CompendContinEduc. Dent. 2013, 8,8-14.

29. Wn,L.; Chang,J.; Zhu, Y.Q.; Zhang,M.; Effect of tricalcium aluminate on the properties of tricalcium silicate-tricalcium aluminate mixtures: setting time, mechanical strength and biocompatibility, Int. Endod. J. 2010, 44(1),41-50.

30. Engqvist,H.; Schultz-Walz, J.E.;Loof,J.; 
Botton,G.A.; Mayer,D.; Phaneuf, M.W.; Ahnfelt, N.O.; Hermansson,L., Chemical and biological integration of a mouldable bioactive ceramic material capable of forming apatite in vivo in teeth. Biomaterials. 2004, 25,2781-2787.

31. Engstrand,J.;Unosson,E.; and Engqvist,H.; Hydroxyapatite Formation on a Novel Dental Cement in Human Saliva, International Scholarly Research Network ISRN Dentistry.2012, 7.doi.org/10.5402/2012/624056.

32. Khaliq, W.; Khan,H. A.; High temperature material properties of calcium aluminate cement concrete, Construction and Building Materials.2015,94, 475-487.

33. Hewlett,P. C.; Lea's Chemistry of Cement and Concrete, $4^{\text {th }}$ Edition, 2003.

34. Oliveira,I. R.;Andrade,T. L.; Jacobovitz, M.;Pandolfelli,V. C.; Bioactivity of calcium aluminate endodontic cement, J. Endod. 2013, 39(6), 774-778.
35. Tam,L. E.;PulverE.;McComb,D.; Smith,D. C.;Physical properties of calcium hydroxide and glass-ionomer base and lining materials, Dent Mater. 1989, 5(3), 145-149.

36. Pires-de-Souza,F. C.;Moraes,P. C.; Garcia,L. F.; Aguilar,F. G.; Watanabe, E.; Evaluation of $\mathrm{pH}$, calcium ion release and antimicrobial activity of a new calcium aluminate cement, Braz Oral Res. 2013, 27(4), 324-330.

37. Orosco, F. A.;Bramante,C. M.; Garcia,R. B.;Bernadineli,N.;Moraes,I. G.; Sealing ability of grar MTA AngelusTM, CPM TM and MBPc used as apical plugs, J. Appl. Oral Sci. 2008, 16(1), 50-54.

38. Kraft,L.; Hermansson,L.; Hardness and Dimensional Stability of a ( Bioceramic Dental Filling Material based on Calcium Aluminate Cement, $26^{\text {th }}$ Annual Conference on Composites, Advanced Ceramics, Materials, and Structures, Cocoa Beach, Florida. 2002, 825- 832. 